\title{
Chinese Literary Avant-Garde: A TAle Of MagiC
}

Alberto Castelli, Hainan University, China, lamezzapunta@yahoo.com

Original scientific paper

DOI: 10.31902/fll.34.2021.1

UDC: 821.581 .09

\begin{abstract}
Chinese Avant-garde stands as a literary avalanche at the economic dawning of the Reform Era. The shaping of postmodern texts depoliticized, and fragmented, is somewhere along the line the ontological transaction to a postideology literature where the permanent struggle is not anymore between classes, but within the frame of personal identities. The narrative moves from socialist realism to experimental writing, from realism to abstract expressionism, forging a literary paradigm alternative to the dominant one. In this sense, Chinese Avantgarde stands as the narrative re-enchantment of Chinese fiction.
\end{abstract}

Keywords: Magic Realism, Surrealism, Avant-garde, Maoism, Postmodernism.

\section{The Plausibility of Magic}

Western and Chinese scholarships have characterized Can Xue's and Ge Fei's narrative as reminiscent of Latin American Magic Realism for the intricate relationship between real and visionary, conceivable and impossible, challenges the grand narrative formulated by the Maoist discourse and before that by the dictatorship of realism. ${ }^{1}$ Furthermore, the same authors have openly admitted to have been influenced by the writing of Borges, Marquez, and Kafka. Not surprisingly, an attentive reader can easily recognize elements of both modernism and postmodernism in their anthology. However, while the parallelism is sound, a closer view will reveal its many flaws. Specifically, my aim in this paper will be to demonstrate what makes the narrative of Can Xue and Ge Fei a moment of continuity and simultaneously a literary rapture with that of Latin American Magic Realism. Magic Realism, is then the theoretical ground from which I shall begin my analysis.

If we could image realism as a literary arch stretching narrative to the limits, Magic Realism would be in between the pole of naturalism and that of the Avant-garde experimentation surrealism, post-

1 The possible relation between Chinese Avant-garde literature and Latin American Magic Realism has not been deeply analyzed by scholarships. Briefly mentioned in: Wedell-Wedellsborg Anne, (1994); Ning Wang, (1997); Zheng Yi, (2004). I reject the artistic overlapping in: Castelli Alberto, (2019). 
expressionism as it comes. It replaces the descriptive, to a certain degree, colorless, understanding of realism with the ambiguity and the anarchy of an aesthetic project whose principles lay within the possibility of an alternative order. A discussion over the origin of the terminology and the carousel of criticism tied in front, fascinating per se, is far from being on my interest here. ${ }^{2}$ The term Magic Realism has been overused among critics and readers, it became fashionable to an extent to be reduced to a cliché, and today it became a concept bon a tout faire, much as postmodernism is, abused for sociopolitical theory more than modernism will ever be. Magical realism, marvelous reality, marvelous realism, fabulism, imaginary realism, are all descriptive designation rather than a rigorous, critical, analysis. Fredric Jameson refers to it as the alternative narrative to the logic of contemporary postmodernism, meanwhile Theo L. D'Haen places Magic Realism within the realm of postmodernism as a cultural branch of the early surrealism (in Zamora \& Faris 1995). Maggie Bowers (2004) sees in it the language of the emergent postcolonial world, and because it became a global phenomenon, an international commodity (Zamora \& Faris 1995) disagreement and confusion are the basics assumptions for a definition. All correct, though what I want to point out is that much of the confusion has been generated by the fact that the connection between the term and its origins has not been properly considered. The use of supernatural or irrational elements within the realm of art goes to wedge off a pre-existent reality and entangles itself within the roots of a specific geographic history. Considering illusion as an ontological element of the human condition, it dealt a blow to the European postEnlightenment rationalism and it became surrealism, it transformed into magic the natural pre-Colombian enchantment of Latin American, and it became an experimental technique in China where for decades literature was virtually denied. When it is understood that magic occurred in many places and times, that it took different forms (symbolist, fantastic, visionary), and names (surrealist, romantic, expressionist), that the boundaries are flexible and vagueness is what most characterizes it, if all this is understood there is no need then for an all-encompassing definition.

However, there is an important reading that cannot be overlooked: Fantastic literature and Magic Realism are two different

\footnotetext{
2 Jeronimo Arellano (2015) offers in footnotes a complete scholarship currently available. To me, the clearest discussion on the nature of Magic Realism in literature is to be found in Amaryll Chanady (1985).
} 
narrative techniques and literary hemispheres. ${ }^{3}$ Marvelous or fantastic is a literary genre that can be traced and found in any chronological period, from Gulliver to Harry Potter, and has well marked the difference between the fictional world and the real one. In this sense marvelous creates a bi-dimensional world with supernatural events and characters on one side and ordinariness as a counterpart. Gulliver is a giant only compared to the inhabitants of Lilliput. On the other hand, Magic Realism is an artistic style that blends together supernatural with natural making of two layers of reality one-dimensional world whose elements are improbable, sometimes highly improbable, but not impossible. Chanady's reading is revealing:

In contrast to the fantastic, the supernatural in magical realism does not disconcert the reader, and this is the fundamental difference between the two modes. The same phenomena that are portrayed as problematical by the author of a fantastic narrative are presented in a matter of fact manner by magical realist (24)

Such integration between fantastic and real is what Amaryll Chanady calls a resolved antinomy in open contrast with the unresolved polarity of fantastic. Grated, a meticulous reader of Garcia Marquez (1927-2014) and Isabel Allende (1942) would notice a tale of performances not likely to happen but holding fragments of possibilities. Hence, it is the gap between improbable and impossible, that fragile layer of action, to render Magic Realism possible and to distinguish it itself from that marvelous it was first created from. I am now ready to harness the question binding this article: Where does Chinese Avantgarde stand? Fantastic or magic? Surrealist or expressionist? What is the use of supernatural in Chinese postmodernism? And why a literature that for centuries adhered to the fittings of realism suddenly bordered the most extreme limits of avant-gardism?

\section{The Fantastic Deconstruction of History}

About around the mid-80s literature in China displayed an entropic tendency that exploded in the 1990s as a clear departure from the messianic aim of socialist realism. ${ }^{4}$ As history is decoded, a decade

\footnotetext{
${ }^{3}$ For a throughout study over fantastic and magic see: Amaryll Chanady (1985), Jeronimo Arellano (2015), and Rosemary Jackson (1981).

${ }^{4}$ Mao understood literature and art as a weapon in the revolutionary struggle and therefore advocated socialist realism, style borrowed from Communist Russia, based on communist utopia and class struggle. Artists were asked to create exemplary models to be emulated, they were told to focus on a progressive stage of a futuristic China (post-revolutionary) instead of engaging
} 
after Mao's death (1976) literature begins to engage with the excess of the recent past. The individual as subject, identity, and body is placed back in the center stage of the narrative, and by so doing Maoist ideology and the current political dialectic socialism-post-socialism is left aside. On the whole, we are given a post ideology literature, an attempt that more analytically combines elements of continental European modernism with the uniqueness of Chinese historical experience. Chinese Avant-garde has to be regarded as the first literary attempt of this new fiction, thus to be grasped in its contextual background, and to be decoded as a turning point in the development of modern Chinese fiction, a moment of Chinese postmodernity. ${ }^{5}$

The historical discussion over Chinese modernity and postmodernity began some three decades ago with Fredric Jameson famously lecturing in Beijing on postmodernism and his groundbreaking definition of postmodernism as the cultural logic of advanced capitalist societies. Ever since, Western and Chinese scholars have restlessly engaged themselves in the attempt to find for China a hamlet under the sun of contemporaneity. Those who have placed China under the empire of the global market have as well placed China under the umbrella of postmodernity. The Chinese scholar Zhang Yiwu addresses the debate from a post-colonial perspective, thus detecting Post-Maoist culture in relation to not so much post-industrialized society as to globalization. Being globalization, thus information, communication a global phenomenon not restricted to the sole West, then China must belong to this global condition of postmodernity. On the other side of the fence, there are those who judge, or have judged, China not mature enough for a postindustrial condition, thus have as well rejected the notion of a Chinese postmodernity. Among them was Professor Wang Ning who, back in the 1990s, considered the infant, socioeconomic condition of China lacking the modernist culture and the material conditions to cultivate postmodernity and a postmodernist literary

\footnotetext{
in a detailed analysis of present conditions (pre-revolutionary), in short life as it might be not as it is.

${ }^{5}$ To distinguish it from the previous production and for its experimentalist nature, Chinese literature in the second half of the 1980s has been defined by Chinese and Western scholars as Avant-garde. For a deeper insight see: Arif Dirlik and Xudong Zhang (2000), Xiaobin Yang (2002), Xiaobing Tang (2000), Zhang Xudong (1997). Scholarships on postmodernity and postmodernism are seemingly endless. This is my selection: David Harvey, (1990); Fredric Jameson, (1991, 1998); Ihab Hassan, (1982, 1987); Linda Hutcheon, (1988); Jean-Francois Lyotard, (1979); John Barth, (1984).
} 
movement. My understanding is that if we leave aside the Marxist theorem, postmodernity becomes a cultural phenomenon rather than a material perspective, and in this sense, Chinese postmodernity has to deal with the socio-psychological condition left in heritage by the Cultural Revolution (1966-1976). The disillusionment with the whole of the national discourse is self-evident; concretely, the texts produced by Can Xue and Ge Fei concede abstract elements to the extent that the shade of magic I described before is turned into fantastic. Can Xue's and Ge Fei's stories, Can Xue more than Ge Fei, are filled with unsettling feelings of uncertainty that span from estrangement to terror, from expectation to anxiety in response to ordinary events. Those are a range of emotions that do not appear in Marquez or Allende for instance; in the case of Chinese Avant-garde, Magic Realism's poetics of enchantment is replaced by a poetics of uncertainty: From the side of the reader, for the same reader cannot entirely assimilate the strange event, and from the side of the author because the supernatural is never absorbed into natural. If reading is a construction of meaning, the problem is that the abuse Chinese Avant-garde makes of the fantastical disturbs the tension between allegorical and reality. Unlike Latin American Magic Realism, the overall significance can never be absorbed into the synthetic stage of the Hegelian narrative, contradictions and doubts remain unsolved within the indeterminacy of a dream. Specifically, this hesitation is suspended in Can Xue because of people who fly or turn into animals unfold according to the logic of dreams, compelling the reading to be a psychological experience; in $\mathrm{Yu}$ Hua (1960) because of the abnormal violence of the narration; and in Ge Fei because of a narrative where the enigma is worth more than its solution. The texts, as a result, do not have a magical realist approach, or magic elements, substituted in some cases by a mysterious atmosphere. and more often by a frightening fantastic. The images are fully charged with allegorical significance, resulting in the plot's content to be less significant than the alternative meaning when it is decoded.

Allegorically, the use of fantastic elements is preparatory for a postmodernist purpose which is the deconstruction of the Maoist discourse. Inherent the narrative is chaos, and chaos helps the writers to open a crack in the wall of ideology, to disintegrate the totalizing experience of the communist rhetoric grounded in the great narrative, the eloquence of national salvation, and the secular collective struggle. Here, is where the process of deconstruction begins, questioning the nature of history, and calling realism into question. And when history was no longer self-sufficient, history began to collapse image by image, piece by piece, bit by bit, emphasizing, framing, caricaturizing, the 
historical violence in the attempt to bring to a halt the aesthetics of the sublime circling Maoist heritage. Consequently, it would not be false to say that Latin American Magic Realism is ontological in a sense that it has its source in the belief and cultural practices of the context it is taken from, while Chinese fantastic is epistemological, for it draws the magic elements from images of the recent past. It is not rooted in Chinese history, but it enlarges as a consequence of the history of China. Ipso facto, next to the ruins of history, the first victim in this process of deconstruction is the subject. The traces of Maoist discourse still lay behind the line of consciousness as an unresolved traumatic memory. Xiaobin Yang reads the Avant-garde as an echo of the Cultural Revolution:

Chinese Avant-garde fiction is a profound textual adventure that re-experiences the inextricable relationship between the hideous atrocities of the past and the captivating discourse that justifies historical violence and invalidates the comprehensibility of the whole situation (50)

The logic behind the narrative of violence, the dissolution of the rational subject in contemporary Chinese fiction is altogether the representation of the irrational the Cultural Revolution was the bearer of, whose violence was inflicted in the name of the proletarian revolution. Simultaneously, the inadequacy of the subject before a linear explanation plays out in the Avant-garde as an oedipal assassination where the father, the Maoist discourse, is murdered through the allegorical alternative. And because some sort of de-sublimation of the transcendence inherent in the Maoist discourse, ideology, the very matrix of Chinese society, is gradually abandoned, disassembled step by step, sided by a multiform attempt of replacement. The twilight of ideology is the secularization of Chinese society.

\section{Inside the labyrinth}

What emerges from the previous pages is that the earthquake of Maoism continues to impact the protagonists' lives far off the next decades. Unlike Latin American Magic Realism, Chinese Avant-garde does not depict an alternative reality but the impossibility of it, so I explain the layer of nihilism behind the literary production. Bei Cun (1965), Can Xue (1953), Ge Fei (1964), Ma Yuan (1953), Su Tong (1963) Sun Ganlu (1959), Yu Hua (1960), are the pioneers, the archexperimentalists of Chinese Avant-garde. My attention here goes for Ge Fei and Can Xue, who did not answer the seduction of the market but remained faithful to the experimental writing. Ge Fei, with his ethereal 
style of narration, corresponds more to the enigmatic happening of Magic Realism, nothing manifestly supernatural is around, yet the mystery and the incapacity from the side of the reader to solve it, shatter irreconcilably the spatiotemporal database of realism. The Invisibility Cloak (2012) stands between Yu Hua's realism, freed of its utter violence, and Can Xue's surrealism voided of hallucinatory inheritance. Vintage speakers and the music of Beethoven protect the postmodernity of Beijing otherwise divided between pessimistic intellectuals and unknown gangsters. The narrator and protagonist, Mr. Cui, is an over forty average-man, childless, and with an unexpected divorce yet to forget. He seems to look down on rich clients and their beautiful wives. Beijing is a city that can drink top brand liquors and throw them up in the bushes. On the other hand, he does not have what it takes: Not rich enough, not ambitious enough, his own wife left him some years before for a more convenient match. Out of passion, he builds hi-fi stereo equipment for wealthy businessmen, though the demand went down in the 90s and he is forced to live in his sister's apartment, sister who wants him out by the end of the year. Betrayed by his wife, tricked by his sister, ignored by his best friend, victim of external circumstances and his own weaknesses, this common man has no recourses to escape the superficiality into which his life floats. The invariability of the plot is briefly interrupted by Mr. Cui's dead mother appearing in a night vision only to shake her head. Not long after, realism is again disturbed by the encounter with Ding Caichen, an ambiguous client who wants 'the highest-quality sound system in the world' and the nameless woman who lives with him. Unreal here is not an alternative narrative dimension, but the reality itself. Partially mystical are the words left unsaid, facts that matter for a global understanding of the novel are only glimpsed instead of being clearly spelled out and explained. Thus, we do not know what terrible action the protagonist's best friend, Jiang Songping, did to Cui's sister many years before, nor we know what the story behind the disfigured face of his second wife is. She does not have a name, and claims to have been kidnapped but the rhetorical question she uses as an answer: "You mean you were kidnapped? I asked in shock/So were you, weren't you? She mockingly replied," (121) hints a reality behind the reality. So she does when pondering the death of Ding Caichen:

Oh, he wasn't distraught'. She corrected me in the same matter of fact tone, as if talking about a total stranger. 'If you ask me, I think he jumped because he finally figured it out. He should've jumped a long time ago (111) 
What did he figure out? Was he a Mafioso forced to commit suicide or a man who felt the spleen of his age? A shade of magic in Ge Fei, unlike in Can Xue, saves the structure of the plot without avoiding making it unreal. Time is twisted; memory becomes a fluid concept assuming different shapes according to different characters. Flock of Brown Birds (2016) might as well be considered the key work of Chinese experimental fiction, a dream of circular logic where the beauty of the prose compensates for the lack of a solid plot. It still moves between the boundaries of realism, but the attempt to undo the convention of realism is omnipresent. In Xiaobin Yang's words: "By unmasking representational realism, Ge Fei's fiction highlights the deconstructive potentials that persist in the process of questioning without giving any determinate answer," (175) which is to say that Ge Fei invented the enigma. Protagonist is a writer, Ge Fei himself, who retreats to the solitude of a publisher-sponsored mansion, Waterside, to finish his novel. Seasons would not change were it not for the brown migratory birds crossing the sky and interfering with the stillness of his time. And for some reason not quite clear to the writer either, he knows that if "the flock were to vanish, they would take time with them" (6). One day the peace of Waterside, where he seems to be the only inhabitant, is broken by the appearance of a mysterious woman dressed in orangered. She carries a large folder, perhaps an art portfolio or a mirror. A portfolio indeed. Qi, her name (Chinese homophone of wife), and she presumes to know him though he has no recollection of her. They sit facing each other all night long, nothing really happens, a cup of coffee is drunken, a story unfolded, there are few intermissions, yet the reader believes in the blurred love story. Time passed. In his emotional retrospect, the sudden death of his wife on their wedding day seems to suggest that time was never enough and as the story ends, Qi takes her leave. Again, it seems too soon. Several seasons later she eventually comes back, but she is just a passerby. Qi claims not to know him as he did at the beginning of the novel. She might not be Qi, perhaps an illusion, the ghost of his former wife; perhaps, she is Qi after all, though she does not remember it, mirroring the narrator's oblivion years before. The story has gone full circle, but it is just misrecognition: In Avant-garde fiction, circularity is broken implying history's lack of unity. The ending scene is identical to the opening one, she is wearing an orange-red dress, she carries in her arms the same canvas portfolio folder, but when she unties the light green strap, the boundless void of the narration is served again: It is a tiny mirror indeed. While a story blends into another, and the characters struggle to recognize themselves, reality does not collapse, but time does, distorted, 
disconnected, confused, eventually forgotten. Memory, at last, is unreliable and so is the author's capacity to find sense in the world.

An inquiry into Ge Fei's labyrinthine fantasy is out of reach. Trying to interpret his story is to run into a dead end street, the symbolism is undecipherable for the meanings are virtually infinite. What is the 'green yellow' (1998) the narrator is looking for in the homonymous story?6 ${ }^{6}$ type of dog, a prostitute, a fleet of prostitutes, nature, or perhaps a book? What is the author's literary scope behind this linguistic investigation? Reminding of Kafka' $\mathrm{S}$ ' $\mathrm{K}$ ' struggling to gain access to the authority of the castle, the narrator wanders aimlessly here and there, asking questions. The fruitless historical investigation starts with the narrator interviewing an old man whose memories are not just fragmented but un-consequential. While recalling the events, he admits not to be sure, he might cover up some secrets altogether. Referring to the arrival of Chang, the ex-boatman and his daughter to the village, he recalls the day he set fire on the boat: "Perhaps he had burned his boat so that the villagers could not refuse him to stay;" "he was probably a good father. Two years later the daughter seemed suddenly grown up" (25). Why did he burn his boat? And what is the semantic relation between Chang being a good father and his daughter growing up? Once again the inconsistency of the narration disavows the unity of the grand narrative, conceptual lacunae, elusive narrative deprive the whole story of unity and fail to pin down the historical truth offering to the reader the choice of a personal reconstruction. Notwithstanding, the reader's imagination and the author's intent, it should be clear by now that the randomness of history and the deconstruction of unity stand as the main aspects of Chinese literary Avant-garde. Ultimately, memory is chaos: In The Invisibility Cloak memory is sluggish, in Flock of Brown Birds the narrative "I" confesses that memory is power, in Remembering Mr. Wu You (1998) village elders hold the painful truth, time erases everything. In Ge Fei, there is an attempt to decipher the past, the search for meaning of Green Yellow, the mysterious, inquisitive $\mathrm{Q} i$, police investigations, but the efforts are to no avail. Fragments and impressions in Ge Fei are incapable of recollecting the whole because of an overall displacement, historical and inter-textual; the past is incorporated in the present, and because the past is blurred the present remains un-decoded. So is Chinese postmodernity.

6 'Green Yellow' trans. Eva Shan Chou. In Wang Jing (ed.), China's Avant-Garde Fiction. Durham: Duke University Press, 23-42. 
Undeniably, the Avant-gardist experimentation is a clear cut with the entire previous production. No traces of political allegory are left; historical realism and roots-seeking lyricism have vanished. The world has been emptied of collective memories. The conscious refusal to delineate a recognizable time, a possible space, takes an oneiric turn as a game of violence. Sexual fantasies, accounts of trivial details, neurotic labyrinths of reason and phantom landscapes filled the vacuum left by ideology. Can Xue, possibly the most imaginative among the experimental writers, unlike them, never left the path of creative writing; she kept producing all along the decades, abstract, expressionist, allegorical stories. The psychic and physical traumas of the communist revolution, the ruins, are everywhere, as a red slogan on a wall, an inexplicable trial or a scar. Difficult to say if her stories stand for a political implication, a cultural breakdown, or a repressed sexuality, but it is manifest that the memories of the Cultural Revolution are distorted into abnormal images that reveal the evil in human nature. The first person narrative indicates that her personal fate and the history of China are indissolubly chained. The endless episode of excrement, putrefaction, stench, anxiety, obsession, are the straightforward allegory of the revolutionary experience turned into a nightmare, human experience debased to death. The narrative ' $l$ ' is equally implicated in the corruption. Insofar, as it was post-war Europe, Chinese artistic task in the $90 \mathrm{~s}$ is to represent the unimaginable, the unpresentable past, and the linearity of realism could not absolve the recital to any degree. Consequently, one observes a palpable fascination with the bizarre, the nightmarish and the brutal. Sadism and torture expose a chaotic reality far from being decrypted, disturbing imagines of uncommon violence accompany the narration whose aim is less about the plot than it is about the recovering of a complex internal state. The rationality or irrationality of Maoist asceticism offers moral legitimation for the loss of memory of her characters who act as moved by unreasonable forces, thus unable to enter history from the door of consciousness. Her memories, included in the foreword to her first short story collection Dialogues in Paradise (1989), provides the historical background for the hunger, fatigue, hallucination, swelling of her literature. Much more a naturalist description than an exercise of experimental fiction:

In 1957 my father, as head of the 'anti-Party clique' at the New Hunan Daily, was condemned as an ultra-rightist and transferred to Hunan Teachers 'College to reform through labor, and my mother was sent to Hengshan Mountain for labor reform. In 1959 the whole family of nine was moved from the newspaper residential 
area to a tiny hut of about ten squares meters at the foot of Yueyushan Mountain. We lived on an income of less the ten yuan per person. That was the time of nationwide natural disaster. Since my father had neither savings nor help from outside, the whole family struggled along on the verge of death (1).

As Marquez's Macondo was based on Arataca, his native place, Can Xue's nightmares take shape from the political persecution her family suffered: The anti-rightist campaign, the reform through labor policy, the down to the countryside movement, the ransacking of the houses during the Cultural Revolution fell upon her childhood, not as a carnival of colors, but the darkest delirium. Exiled to an insignificant hut, forced to lick an empty bowl of porridge to remember the taste, those summer nights at the foot of Yueyushan Mountain represent for the young Can Xue a world apart at the edge of life. The moment her grandmother would drive ghosts away with a stick, grasshoppers, beetles, crickets, owl, and snakes would fill the earth, "a terror of loneliness and helplessness overwhelmed me" (10). Ten years went past; time became literature and literature imagination. Reality is an illusion, a Kafkaesque labyrinth of possibilities where very little is the space occupied by the narrative plot. The initial logical sequence is soon denied by rocking scenarios of paranoia and obsession, the narrative is broken into impossible hallucination and incomprehensible fragments of voices that never become a dialogue. Accordingly, all the scenes are distorted, explicable only if interpreted as oneiric visions, yet the surrealist visions are blend with the banality of real and the fear of every day. Ghosts, mythical beasts, magic, the bottomless abysses of mystery offer an alternative allegory where the original meaning is lost forever, and man has lost his freedom.

In this regard, Can Xue places her work within a form of writing that I have already excluded from the category of Magic Realism where the plot is well defined. Nor does she rely on a recognizable version of reality to support her magical aspects; in fact, the plot is structured around an inner, hidden, logic. Her narrative is reminiscent of that Comte de Lautreamont (1846-1870), whose quote "As beautiful as the chance encounter of a sewing machine and an umbrella on an operating table" inspired Aragon, Breton and the surrealist festival. ${ }^{7}$ The

\footnotetext{
${ }^{7}$ Alejo Carpentier in El Reino de este mundo $(2009,1)$ to define what marvelous is not refers to the well famous statement left by Comte de Lautréamont (18461870). Pseudonym of Isidore Lucien Ducasse, Lautreamont was a French poet
} 
juxtaposition of everyday objects placed in unexpected settings was the surrealist belief, as much as, the unpredictable encounter of disparate objects and events, -of realities that by all appearances have nothing in common-, is Can Xue's narrative. Accordingly, being subject and object so far apart from each other, reason fails to connect them. Exemplification is the well-known short story The Hut on the Mountain (1986), quintessential of Can Xue's writing. ${ }^{8}$ The unreasonable suffering is not given by a specific happening, but by the menacing atmosphere oppressing the whole. Violence here is psychological, the reader remains with the awkward feeling that something had been violated: The narrator's intimacy, childhood, past, perhaps her virginity. She sees countless tiny holes poked by fingers in the window screens, the wolves poke their heads in through the cracks on the door, her desk drawers have been searched and now something is missing. The world 'swollen' appears three times, twice referring to the narrating ' $I$ ' 'my swollen head on the pillow,' 'the spot would become numb and swollen whenever she did that,' once referring to her mother being beaten by a bug hidden in her shoes 'her whole leg was swollen like a thick lead pipe.' It might not have a political implication, but it evokes the traumatic effects of physical suffering. Compulsive characters act within the space of a few pages without a sequitur. Fear is a general threat, Sartre's aphorism the hell is the other finds here a natural dimension. The mother is tortured by the sound of the opening drawers: "She was so tortured by the sound that every time she heard it, she'd soak her head in cold water until she caught a bad cold" (215), the father has been haunted for twenty years by a pair of scissors dropped at the bottom of the well. Matters of fact, no scissors have ever fallen into the well. The protagonist ' $I$ ' is obsessed by her drawers, -opening and shutting them closed becomes a ring on the chain of madness rather than a daily routine-, and by the others. She is hypersensitive to sounds, she is kept awake by the thieves wandering at night, the man in the hut banging against the door, big rats running in the wind, rocks rolling down the mountain, her father howling. Nevertheless, as the source of disturbance is undiscovered, we might deduce as well that dangers and threats are products of the narrator's hallucinated imagination. "Everything has its own cause from way back. Everything" (215) is the allegorical statement embodying the meaning of the story, if a meaning there is at all. The hallucinating sequence of events, the man locked up in the hut, the father turning into a wolf at

born in Hungary recognized as a major influence on the next to come Surrealist movement.

${ }^{8}$ Can Xue, "The Hut on the Mountain", in Jing Wang (1998, 212-216). 
night, the invasion of bugs at daybreak are a clear recall of Kafka's metamorphosis, but it is the possibility of violence lingering within the narration, (the mother thinking of breaking the ' $\mathrm{l}$ ' narrator's arms, the father thinking of committing suicide) to call out the universe of symbolism.

While in Yu Hua, Chinese Avant-garde is represented by a traumatized and traumatizing external reality, and in Ge Fei by an aesthetic possibility, in Can Xue, it takes the shape of a hallucinated and hallucinating internal world. Based on her recollection, we should decode her narrative as vertical, cutting directly into the heart of darkness. The lack of cohesiveness between time setting and narrative elements creates a gap in meaning lodging her fiction in a space beyond the logic of the reader. Additionally, the stream of consciousness of her language establishes a world autonomous from reality and reason. Therefore, because with Can Xue, realism enters the kingdom of dreams, scholarships have labeled her writing as an expression of madness. ${ }^{9}$ Undeniably, her characters move around the borders of perversion, schizophrenia, and paranoia. Charlotte Innes writes in her preface to Old Floating Cloud (1991): "To read Can Xue is more like falling asleep over a history book and dreaming a horribly distorted version of what you have just read" (XVII). Due to the shaking structure of the narrative and the protagonists' struggle to survive, the 'ideal-type' of realism and socialist realism is split into myriads of ' $I$ ' reflecting each other. There no escape, no qualitative difference between the land left behind and the found one, the overall helplessness outlives the attempt of recollection, reconstruction, for those who survived. My understanding is that this is the author passing judgment on history, not just the Chinese teleology of modernization, but history itself. Marquez's narrative develops along the diatribe between Liberal and Conservative party, Allende's stories unfold within the dictatorship of Pinochet, Ge Fei bypasses the grand history, but many of his fictional texts can be understood as parodies of Chinese historical past, The Lost Boat (1989) and Whistling (1990), for instance, stand as contamination of orthodox historical images and figures. However, in Can Xue, if we did not know of her context, nothing would remind of China, she does not draft any realist setting recognizable in relation to the past or the present reality, cultural identity is virtually inexistent, characters are nameless, thus turning history from local to universal. If we were to sketch the plot of The Last Lover (2014), it would be something like: In a

9 See Ann Wedell-Wedellsborg: (1994); Jon Solomon (1988); Susanne Posborg (1993). 
never-named city of an unknown Western country, Joy, the closest being the novel has to a protagonist, confuses the real world and the fictional one of the novels he reads. That would be all. Magic farms and wheelchair floating in the air provide the outline for magic with no foundation; few characters appear as a similar version of each other, space, as much as time, is ambivalent and multidimensional. Meanwhile, the reader, placed a step above Calvino and Borges, is plunged into a virtual realism whose nature is intentionally left unqualified: "An abyss opened in the sidewalk ahead of him, and he walked toward it, thinking perhaps it would lead him into the web of the story he had recently constructed" (22). On the whole, the structure of her stories is fragile, the buildings are about to collapse, the ocean threatens the mountain, people are suddenly beaten, violence emerges unexpected, insignificant details as a glance, or a word, become antechamber of ceaseless fear. As in Ge Fei, mysteries remain inextricable, though her vision of life overstretches the boundaries of allegory and becomes a threat to the official psychology. The short story Snake Island is emblematic of Can Xue's menacing fantastic: An unknown narrator ' $I$ ' goes back to his hometown after thirty-one years to finally take care of his father's grave and visit the allegedly still alive Uncle San. ${ }^{10}$ But the place is desolated beyond recognition; the mountains are gone and so are the trees replaced by tasteless bungalows. He begins questioning random people about his uncle's house. At first, a farmer's wife asks him whether he is already dead or not; not later a middle-aged man sets the tone of the narration offering a hint to decode it:

You have to change your mental concept of the village (...) You ask where he is. This question is asked only by people unfamiliar with our situation (94)

What is 'our situation'? The reader is already displaced in a noone zone where the presence of death, - opened graveyard, possible ghosts appearing at night- is sided by a grotesque reality. We are given a scene where the confused and tired protagonist is sitting on a rock in a cemetery. Surrounded by opened graves with no tombstone, and bones scattered around, he is taken by a sudden hunger. Hence, he opens his suitcase and begins eating sausages. The duality invests the text with an ambiguity disturbing for a reader in search for meaning, the ghosts are just as real as the people alive or rather those alive are just as unreal as ghosts. Against his own perception, the narrator is believed

${ }^{10}$ In "Blue Light in the Sky \& Other Stories" (2006). 
to be dead, but he has no grave, and he is looking for the dead and because the reader cannot decipher his status, neither can he puzzle out the text. Can Xue imagines her protagonist's childhood village as a smooth switch between two dimensions, the living and the dead, adding the features of unreality and timelessness to that of displacement. Sure enough he could be the last comer in the afterworld; Uncle San gives another clue in this sense. During a small talk with the narrator, referring to the people coming out from the graveyard at night, he declares twice "I think they are people like you" (96) and a few pages later "You are one of them" (100). Like you meaning alive, dead or graveless? The doubt remains. His understanding of the past comes as an enlightenment: Nothing can really be forgotten, and yet, in the end, present and past do not match anymore. The aesthetics of Avant-garde tends towards silence, the line at which life and death finally meet. Who is what, is the question leading Can Xue's narrative, unfortunately not even the end of the story will clarify the nature of the tale. The open-ended conclusion of Ge Fei, and the circularity of Latin American Magic Realism, both suggesting that life will continue, and so will history, is replaced here by the total absence of conclusion, the episodes are pieced together without lightening the obscurity of the whole. "There were no grapevines, nor any hut" is the matter-of-fact sentence she writes to end The Hut on the Mountain which is on par with the scissors dropped in the well in the same story, both disturbing images if we consider that the text never refers to the grapes, nor have scissors ever fallen into the well. We might be dealing with an allegory of the incomprehensibility of history. Can Xue seems to be an author that writes fiction from a loss of memory zone, without regard for the reader's need of special orientation. There has to be complicity between the writer and the reader, a shared moment of understanding where reason is dominant over irrationality and reality privileged over dream. This is missing in Can Xue, the reader never knows where he is, with the result of losing the potentiality of the text.

In conclusion, both genres, Latin American Magic Realism and Chinese Avant-garde, are produced in the aftermath of a more or less defined historical upheaval. For them not only the task to come to terms with the most recent past, but also to define their position in the new present, which is the global market economy. Thereupon, the Chinese experience is much more 'revolutionary' ignoring point-blank the logic of marketization. They share the notion of a national failure, a sense of tragedy. Macondo, Comala, Santiago, Baires, Avana, Beijing, Shanghai share realities of civil wars, domestic abuses and foreign exploitation, personal solitude and national drama. The experience of different 
degrees of magic plays out as a strategic tool aiming to deconstruct the official history. Simultaneously, the disruption of fixed categories of understanding allows the writers to create a space outside the totality of real where the unspeakable can be expressed, at last. In the case of China, the official historiography is inadequate to understand the stormy past; there is an evident attempt, from the side of the authors to not repressing the past into oblivion as to avoid falling into the its abyss once more. Only by relinquishing the burden of the past can they elude the fate of the Buendias, "races condemned to one hundred years of solitude do not have a second opportunity on earth" (Marquez, 327). Ergo, the linearity of rationality is sided by circularity, irrationality, fatalism, and isolation whose details overwhelm the accommodating visions elaborated by the mainstream production. Among others, Can Xue and Ge Fei correspond to the turning point of the new novel, far apart from political ramifications, shouldering the outcome brought by new experimental techniques. While fantastic brings down the empire of history, magic more than socialism stands as the proletarian struggle against injustice.

\section{REFERENCES}

Alejo Carpentier, El reino de este mundo. New York: Rayo/Harper Collins, 2009.

Arif Dirlik and Xudong Zhang, editors. Postmodernism \& China. Durham \& London: Duke University Press, 2000.

Amaryll Chanady, Magical realism and the fantastic: Resolved versus unresolved antinomy. New York: Garland, 1985.

Can Xue, Dialogues in Paradise. Translated by Ronald R. Janssen and Jian Zhang. Evanston, III: Northwestern University Press, 1989.

. Old Floating Cloud: Two Novellas. Translated by Xu Ying and Fern Janssen. Evanston, III: Northwestern University Press, 1991.

. Blue Light in the Sky \& Other Stories. Translated by Karen Gernant \& Chen Zeping. New York: A New Direction Books, 2006.

. The Last Lover. Translated by Annelise Finegan Wasmoen. New Haven \& London: Yale University Press, 2014.

Castelli, Alberto. "The Disenchantment of History and the Tragic Consciousness of Chinese Postmodernity." CLCWeb: Comparative Literature and Culture 21.4 (2019): <https://doi.org/10.7771/1481-4374.3085>

David Harvey, The Condition of Postmodernity. Oxford: Blackwell Publishers, 1990.

Fredric Jameson, Postmodernism or, The Logic of Cultural Capitalism. London: Verso, 1991.

. The Cultural Turn. London: Verso, 1998.

Gabriel Garcia Marquez, One Hundred Years of Solitude. Translated by Gregory Rabassana. New York: Avon Books, 1971. 
Ge Fei, The Invisibility Cloak. Translated by Canaan Morse. New York: New York Review Books, 2012.

. Flock of Brown Birds. Translated by Poppy Toland. Beijing: Penguin Classics, 2016.

Ihab Hassan, The Dismemberment of Orpheus. Toward a Postmodern Literature. Wisconsin: The University of Wisconsin Press, 1982.

. The Postmodern Turn: Essay in Postmodern Theory and Culture.

Columbus OH: Ohio State University Press: 1987.

Jean-Francois Lyotard, La Condition postmoderne. Paris: Editions de Minuit, 1979.

Jeronimo Arellano, Magical Realism and the History of Emotions in Latin American. London: Bucknell University Press, 2015.

Jing Wang, editor. China Avant-Garde Fiction. Durham \& London: Duke University Press, 1998.

John Barth, The Literature of Replenishment, The Friday Book: Essays and Other Non-Fiction. London: The John Hopkins University Press, 1984.

Linda Hutcheon, A Poetics of Postmodernism: History, Theory, Fiction. New York: Routledge, 1988.

Lois Parkinson Zamora and Wendy B. Faris, Magical Realism: Theory, History, Community. Durham \& London: Duke University Press, 1995.

Maggie Ann Bowers, Magic(al) Realism. New York: Routledge, 2004.

Ning, Wang. "The Mapping of Chinese Postmodernity." Boundary 2 24, no. 3 (1997): 19-40. doi:10.2307/303705.

Solomon, Jon. "Taking Tiger Mountain: Can Xue's Resistance and Cultural Critique." Modern Chinese Literature 4, no. 1/2 (1988): 235-62. http://www.jstor.org/stable/41490638.

Wedell-Wedellsborg, Anne. "Ambiguous Subjectivity: Reading Can Xue." Modern Chinese Literature 8, no. 1/2 (1994): 7-20. http://www.jstor.org/stable/41490723.

Wendy Larson and Anne Wedell-Wedellsborg, editors. Inside Out. Modernism and Postmodernism in Chinese Literary Culture. Aarhus: Aarhus University Press, 1993.

Xiaobin Yang, The Chinese Postmodern. Trauma and Irony in Chinese AvantGarde Fiction. Ann Arbor: The University of Michigan Press, 2002.

Xiaobing Tang, Chinese Modern. Durham \& London: Duke University Press, 2000.

Zhang Xudong, Chinese Modernism in the Era of Reform. London: Duke University Press, 1997.

\section{AVANGUARDIA LETTERARIA CINESE: UNA STORIA DI MAGIA}

Questo manoscritto inizia con uno studio analitico del realismo magico e della letteratura fantastica, in modo da distinguere l'uno dall'altro. L'analisi testuale dei romanzi latino-americani diventa strumentale per respingere l'approssimazione accademica che vuole la scrittura sperimentale cinese come 
evocativa della narrativa di Borges e Marquez. L'articolo suggerisce che la narrativa postmoderna cinese nella sua eccezione avanguardista non ha un approccio magico realista, ma surrealista. La poetica dell'incanto proprio del realismo magico è sostituita da un fantastico spaventoso, un sentimento di incertezza che spazia dall'estraneità al terrore, dall'attesa all'ansia in risposta agli eventi ordinari. Nella sua interezza, distinti strati di fantastico costruiscono una narrativa che decostruisce la storia ufficiale, e simultaneamente sostiene la lotta post-proletaria contro l'ingiustizia.

Parole chiave: Realismo Magico, Surrealismo, Avanguardia, Maoismo, Postmodernismo. 